\title{
The Effect of the Internal Audit Roles and Auditor Professionalism on Fraud Prevention*
}

\author{
Ela Nurlaela ${ }^{1}$, Ratna Mappanyukki $^{1} \&$ Dwi Asih Surjandari ${ }^{1}$ \\ ${ }^{1}$ Universitas Mercubuana, Jakarta, Indonesia \\ Correspondence: Ela Nurlaela, Universitas Mercubuana, Jakarta, Indonesia.
}

Received: August 13, 2021

doi:10.11114/smc.v9i2.5324
Accepted: September 9, $2021 \quad$ Online Published: September 16, 2021

URL: https://doi.org/10.11114/smc.v9i2.5324

\begin{abstract}
This research aimed to find the internal audit roles $\left(\mathrm{X}_{1}\right)$ and the auditor professionalism $\left(\mathrm{X}_{2}\right)$ at Fraud Prevention in NJC Bank in Kuningan Regency. Samples of this research were the NJC Bank employees. The data collection used in this research is the questionnaire method and the data processing used the SPSS program. The analysis results show that the role of the internal auditor has a significant effect on fraud prevention $\left(\mathrm{H}_{1}\right)$, the auditor professionalism significantly affects fraud prevention $\left(\mathrm{H}_{2}\right)$, and the test results simultaneously show that the two independent variables have a significant effect on fraud prevention. Supported the results of the implication of this analysis is to improve the roles of the internal auditors and the professionalism of auditor internal could increase fraud prevention.
\end{abstract}

Keywords: internal audit role, auditor professionalism, fraud prevention

\section{Introduction}

Indonesia is one of the countries with an extraordinarily high level of fraud cases that can be considered deviant or dishonest acts. These acts can form in deception or dishonesty generated by the human mind to take advantage of others. Each organization - both government and private - risks any fraud or corruption (Soepardi, 2012).

Fraud in an organization is a preventable risk. This phenomenon cannot be completely removed, but it can be minimized. The risk of this fraud can be minimized by regulating and establishing a well Internal Control System. A good Internal Control System can prevent fraud (Soepardi, 2012).

Fraud prevention is the first step in reducing the opportunity to conduct fraud which applies soft control in form of good work culture in a company (Albrecht, et. al., 2011). Suastawan, et. al., (2017) in their study suggest that organizational culture can be defined as norms, values, assumptions, beliefs, and habits created in an organization and approved by all members as the guidelines or references for the company to carry out the activities, both for the internal and external interests. Meanwhile, Schein (2004) stated that organization culture refers to the pattern of basic assumptions considered valid and worked in an organization. Those assumptions can be learned and comprehended by the organization members in which they can play a role as the problem solver for the company issues and be the balancer for the factors developed outside the organization and in integrating the internal of their members or employees.

One of the factors that can prevent fraud, according to Arens, et. al., (2008, cited in Zelmiyanti and Anita, 2015), is by implementing the honesty and high ethic culture. This Arens and friends' theory is supported by the study by Tunggal (2010) which suggests that fraud can be prevented by improving the organizational culture where the employer and the employees implement the principles of Good Corporate Governance. The banking stakeholders are obligated to apply good cultures in their company to minimize and even prevent any kinds of fraud.

The banks are obligated to improve the organizational culture of their company to prevent any fraud, improve their banking performance, protect the stakeholders' interest and increase the obedience of the laws and regulations, and the ethic code or code of conduct prevailing generally in the banking industry (Zelmiyanti and Anita, 2015). Since the bank is one of the companies that provide service products, it is necessary to keep the banking culture optimal. The culture in this term refers more to the cultures that can prevent fraud. According to Tunggal (2011), an honesty culture and high valued ethics can prevent any fraud in a company or organization.

${ }^{*}$ Research at NJC Bank in Kuningan Regency 
Good cultures can significantly affect the regular and organized pattern of human behavior since culture can reflect the appropriate attitude in certain circumstances. Organizational culture is a set of values and norms believed by people in an organization to achieve their goals (Wati, 2019). Since organization culture is likely to determine the achievement of organization goals, the management stakeholders or the leaders need to comprehend well the organization culture embraced by their employees and how to direct it optimally to reach the organization goals effectively and efficiently.

The internal control systems in the banking industry are closely related to the organization culture, where according to Robbins (2002), this culture functions as the feeling creator and the control mechanism that guide terms of the employees' behavior and attitude. Those who are new in the company mostly cannot follow all the regulations that have been prevailing there, however, seeing the role model for the habits and cultures from the former employees would likely drive them to obey and embrace all the laws and regulations that have been established. It is when the organization cultures become firmly embraced by the whole population in the company that the internal control system would be more effectively conducted. This effective internal control system will hold down any fraud in any bank or company (Zelmiyanti and Anita, 2015). In this term, the internal auditor functions to evaluate and advise the process of internal control systems.

The research on organization cultures by Rangga (2015) has proven that the factors of organization cultures include the transaction between the parties with a special relationship which significantly has a negative effect on the tendency to accounting fraud. Meanwhile, the research on the effect of the internal auditor on the internal control system conducted by Neli (2009) suggests that internal auditor affects the implementation of the internal control system. Furthermore, there is also a study of how organizational cultures affect the internal control system in Yogyakarta Rural Banks or Bank Perkreditan Rakyat (BPR) Yogyakarta conducted by Riba'ati (2003, cited in Zelmiyanti and Anita, 2015) which shows that organizational cultures affect the implementation of the internal control system, especially in cash management issues.

Some fraud cases in Indonesia begin from the inappropriate corporate governance and the dishonesty culture occurring in the company since those frauds occurred firstly from the internal financial issues. In this case, the internal control systems have not been carried out optimally since they are the internal parties themselves who started the fraud cases (Zelmiyanti and Anita, 2015). On the other side, it is the internal auditor that appears to be weak which is proven by the discovery of many fraud cases revealed by the Indonesian Bank checking.

The higher the level of fraud occurring in Financial institutions forces the board of institution directors to pay special attention and give varied efforts as fraud prevention in their working area. A bank is one of the financial institutions that conduct any effort to maximize the internal audit roles to minimize fraud.

Indonesia is a country with an extraordinarily high degree of fraud cases. This can be seen from the amount of fraud occurring in the banking world during 2014-2016. Tampubolon (2016) explains that credit cases dominated the banking fraud as $55 \%$, accounting manipulation as $22 \%$, fund embezzlement as $15 \%$, fund transferring as $5 \%$, and asset embezzlement as $4 \%$.

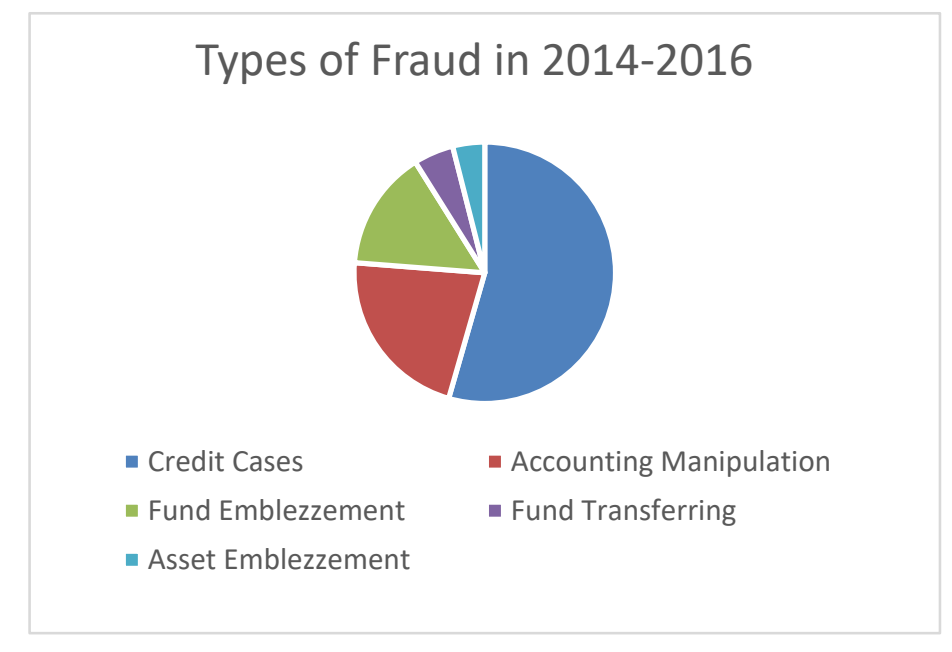

Figure 1. Types of Fraud in 2014 - 2016

Source: OJK Data 2016

Bank operational activities were overseen by Financial Services Authority (OJK). Seeing the urgency of fraud tackling and prevention, OJK establishes the regulation of the implementation of internal audit functions on Commercial Banks that is the Republic Indonesia Regulation of Financial Services Authority number 1/POJK.03/2019 about the implementation of internal audit functions on Commercial Banks including the internal audit roles in preventing and detecting frauds. 
Fraud prevention and tackling are some of the things that are considered necessary in Indonesia. OJK as the institution that oversees the banking activity applies the regulation of the implementation of internal audit functions on Commercial Banks including fraud prevention. The strategy implementation of fraud prevention on Commercial Bank is established in Indonesia Bank Regulation Number 13/28/DPNP on December 9, 2011. According to the Indonesia Bank Regulation, the fraud prevention strategy comprises four pillars, namely: 1) Prevention, 2) Detection, 3) Investigation, Reporting, and Sanction, 4) Evaluation Monitoring and follow-up the system implementation.

Bank BNI applies five pillars of fraud prevention, referring to POJK No. 39/03/2019 regarding the implementations of anti-fraud strategies in Commercial Banks. In implementing the first pillar, BNI establishes a good work culture, including Fraud Awareness, facts of integrity, and 46 principles that ensure the integrity of every BNI employee (Bob, 2021).

The earlier researches show the inconsistency among the researchers. Some research indicated that auditors' professionalism would likely increase job satisfaction. Similarly, locus of control has a significant effect on the job satisfaction of auditors. High job satisfaction will significantly improve the auditors' performance. Several studies conducted by Astuti and Sormin (2019) suggest that professionalism does not have a positive effect on the ability to detect fraud. That is, the attitude of professionalism does not necessarily reflect whether internal auditors can be professional or not.High job satisfaction will significantly improve the auditors' performance (Dali and Mas'ud, 2014). Another result of the research shows that professionalism has no significant effect on fraud prevention (Widaningsih and Hakim, 2015), while Listriyantie (2016) shows that professionalism significantly affects fraud prevention and detection. In some researches on internal auditors, there is a positive correlation such as the research conducted by Gusnardi (2011) which suggests that audit committees, internal audits, and company internal control significantly affect fraud prevention. This is in line with the research done by Petrascu and Tieanu (2014). Some researchers argued that internal audit cannot affect preventing fraud since there is no clearance of internal audit role and position. Government regulation states that internal audit belongs to management control while its tasks are inspecting the management control (Munteanu, et al., 2010). The system of internal control has a positive correlation with fraud prevention (Surjandari and Martaningtyas, 2019). The difference in findings of previous researches gives space to other researchers to test the correlation of both variables.

Coming from those phenomena and inconsistent research results, the problems are formulated as follows: a) How do the internal audit roles affect fraud prevention, b) How does professionalism affect fraud prevention.

\section{Theoretical Background and Hypothesis}

\subsection{Fraud Prevention}

The first step in reducing the opportunity or chance to do the fraud which applies soft control in form of good work culture in a company is defined as fraud prevention (Albrecht, 2011). Fraud prevention is defined by Tunggal (2012) as an integrated effort to repress the causal factor of the fraud, while the advantage of fraud prevention is to reduce the loss made by the fraud. The incompetent and weak internal audit of a company can cause the fraud prevention to run badly and be ineffective (Hery, 2010). Fraud prevention can be done by forming a good structure of the internal control, streamlining the internal control, and the internal audit function (Amrizal, 2004).

Nurhayanto (2013) in his book explains that some causal factors of fraud prevention in financial reports are to adjust the target and goals of the company, in this case, is principal, to increase the stock sale and to increase the incentives for the employees or agents. Therefore, it needs the commitment among the management, employees commitment, resources, and employment network. If linked to the agency theory, fraud prevention done highlights the agent roles in gaining the profit achievement of the company since fraud can cause a great loss. It is such the evaluation and prevention of the fraud, formation of an anti-fraud environment, and elimination of the opportunity to do fraud that can be one of the fraud prevention ways for agents or principals (Albrecht, 2012).

One of the factors that can prevent fraud, according to Arens, et. al., (2008, cited in Zelmiyanti and Anita, 2015), is by implementing the honesty and high ethic culture. This Arens and friends' theory is supported by the study by Tunggal (2010) which suggests that fraud can be prevented by improving the organizational culture where the employer and the employees implement the principles of Good Corporate Governance. The banking stakeholders are obligated to apply good cultures in their company to minimize and even prevent any kinds of fraud.

The banks are obligated to improve the organizational culture of their company to prevent any fraud, improve their banking performance, protect the stakeholders' interest and increase the obedience of the laws and regulations, and the ethic code or code of conduct prevailing generally in the banking industry (Zelmiyanti and Anita, 2015). Since the bank is one of the companies that provide service products, it is necessary to keep the banking culture optimal. The culture in this term refers more to the cultures that can prevent fraud. According to Tunggal (2011), an honesty culture and high valued ethics can prevent any fraud in a company or organization. 


\subsection{Internal Audit}

Hery (2010) defines an internal audit as an assessment function developed freely in an organization to test and evaluate the activities as the services form of a company where the internal audit has professional standards in carrying on the tasks. While according to Sawyer (2006), internal audit is a part of company activities that obligates to help management in giving additional information about corporate governance aiming to add the company value.

"Internal audit is an independent activity, objective conviction, and consultation that are designed to add value and increase the operation of the organization. This internal audit helps the organization to reach its goal by conducting systematical approach and discipline to evaluate and increase the effectiveness of risk management, control, and the process of governance." (Institute of Internal Auditors, 2005)

The dimension of the internal audit includes compliance, verification, evaluation, recommendation, and scope of work. Internal Audit has an important role in the case of corporate management and the related risks in running the business (Sawyer, 2006:7).

Kumaat (2011:12) explains that internal auditor has roles as managing partner in achieving the goals, which is related to the new paradigm about internal auditor roles. This is not in line with the research conducted by Ginanjar and Syamsul (2020); Maliawan, et al. (2017); and Marsandy and Rahmaita (2018) which suggest that internal auditor roles affect significantly on the fraud prevention. It means that internal audit roles and fraud prevention have a strong correlation. The better the internal audit roles, the higher the fraud prevention.

\subsection{Professionalism}

"Professional means responsibility for conduct that extends beyond satisfying individual responsibilities and beyond the requirements of our society's laws and regulations. (American Institute OfCertified Public Accountants (AICPA) in Arens et.al., (2012:129)). An auditor should have: 1) Special training on the internal auditor to support his/her tasks, 2) Commitment to obey the ethical code as the member of internal audit, 3) Participation to be the member of the association and attend the meeting with the fellow internal auditor in The Institute of Internal Auditor (IIA), 4) Journal publication to increase the ability of an internal auditor, 5) Taking the CIA (Certifies Internal Auditor) test and acquire the certificate, 5) License from the state or certification from the Board of Internal Auditor Profession (Sawyer, 2006:10).

The professional ability ought to be owned by every internal auditor. According to Hery (2010), seen from the agency theory, the main purpose of the agent in actualizing the principal interest is done by minimizing the loss created by the fraud. With the existence of a good internal audit, it is supposed to reach the agent's interest. In selecting the internal audit officer, the agent must thoroughly consider, facilitate and develop the ability of the internal audit team both in case of their soft competence and hard competence (Kumaat, 2010).

An internal auditor should have professional behavior in carrying out his task. This is quite important since, with professionalism, an auditor can show a good attitude and performance. The internal auditor can gain a wide knowledge of the complexity of a company or organization. Besides, high professionalism can guarantee the auditor's freedom (Wijaya and Pesudo, 2020). An internal auditor's performance significantly affects the process of the company activities and the trial to reach the organization's goals (Ramadhaniyati and Hayati, 2014). When an internal auditor owns independence and good professionalism, the try of fraud prevention can be easier to carry on. Professionalism quite affects fraud prevention since the auditor can share his objective, unbiased and unlimited opinions and suggestions.

Auditor professionalism has a significant effect on fraud prevention (Fullerton and Durtschi, 2004). According to Listriyantie (2016); Wijaya (2010); Andriyanti and Latrini (2019); and Wulandari and Nuryanto (2018), the professionalism of the internal auditor has a positive effect on the effort to prevent fraud. Meanwhile, Wulandari (2014) and Widaningsih and Hakim (2015) suggest that auditor professionalism gives no significant effect on detecting fraud. Based on the theoretical framework, it can be drawn in research model as follows: 


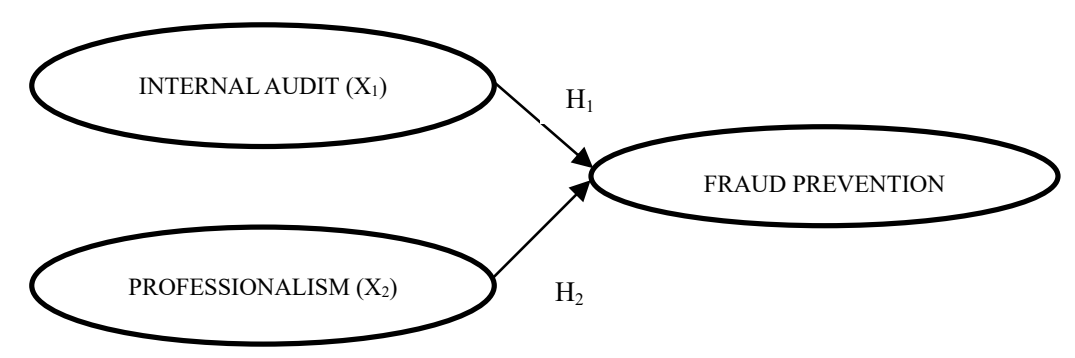

\section{Hypothesis}

Based on the literature and research gap explained above, it can be hypothesized as follows:

$\mathrm{H}_{1}$ : "Internal Audit Roles has a significant positive effect on fraud prevention"

$\mathrm{H}_{2}$ : "Auditor Professionalism has a significant positive effect on fraud prevention"

\section{Research Method}

\section{Research Design}

The design of this research is causality research used to test the hypothesis between some determined variables. These variables consist of the independent variable and dependent variable. The variables in this research include Fraud Prevention (Variable Y) which belongs to the application of work culture (soft control) incorporate operation (Albrecht, et. al., 2012), Internal Audit (Variable $\mathrm{X}_{1}$ ) which includes compliance, transaction evidence, evaluation, and recommendation (Sawyer, 2006:7), and Internal Auditor Professionalism (Variable $\mathrm{X}_{2}$ ) which includes audit training, the certification test of audit training (Sawyer, 2006:10).

\section{Research Population and Sample}

The population is a region of generalization consisting of an object or subject which has a certain quality and characteristic determined by the researcher to be studied and then draw the conclusion. A sample is a part or some amount and characteristic owned by the population (Sugiyono, 2010:90). In this research, the population is the auditor of NJC Bank in the Kuningan Region.

The sample is a sub-group or a part of the population (Sekaran, 2014:123). The probability sampling used in this research is a simple random sampling that takes the sample from the population randomly without considering the class or levels in the population (Sugiyono, 2010:82). The total sample in this research is 277 people. Meanwhile, the data collected is primary data using the Likert scale.

\section{Analysis Method}

The analysis method used in this research includes a) Descriptive statistical analysis including data quality test and classical assumption test. In the data quality test, there are data validity and data reliability test. In classical assumption tests, there are Normality Test, Multicollinearity Test, and Heteroscedasticity Test. b) Hypothesis test includes T-test and determination coefficient test (R2). c) Simple Linear Regression Test and Doubled Linear Regression Test.

The regression equation for each hypothesis is: Hypothesis 1. the effect of internal audit roles on fraud prevention $\mathbf{H}_{\mathbf{1}}$ : $\mathbf{Y}=\mathbf{a}+\boldsymbol{\beta}_{1} \mathbf{X}_{1}+\mathbf{e}$. Hypothesis 2. the effect of professionalism on fraud prevention $\mathbf{H}_{2} \mathbf{Y}=\boldsymbol{a}+\boldsymbol{\beta}_{2} \mathbf{X}_{2}+\mathbf{e}$. With $Y=$ Fraud Prevention; $X_{1}=$ Internal Audit; $a=$ Constanta; $\beta=$ Slope or regression coefficient or intercept; $e=$ error.

\section{Result of Statistic Test}

\section{Data Quality Test}

\section{Validity Test}

Based on the result of the instrument test with validity test, it can be found out that all indicators from each variable that it internal audit roles, auditor professionalism, and fraud prevention, are indicated valid since on the whole indicator has the value of r-count higher than r-table (0.117).

\section{Reliability Test}


Table 4. Result of Reliability Test

\begin{tabular}{lll}
\hline Variable & Cronbach's Alpha & Conclusion \\
\hline Internal Audit Roles & 0.899 & Reliable \\
\hline Auditor Professionalism & 0.903 & Reliable \\
\hline Fraud Prevention & 0.896 & Reliable \\
\hline Source: SPSS 24 Data Processing Result $(2020)$ & \\
\hline
\end{tabular}

The Cronbach's alpha value on each variable which is internal audit roles, auditor professionalism, and fraud prevention is higher than 0.60 so it can be concluded that all variables are reliable.

\section{Classical Assumption Test}

\section{Data Normality Test}

The Cronbach's alpha value on each variable which is internal audit roles, auditor professionalism, and fraud prevention is higher than 0.60 so it can be concluded that all variables are reliable.

From the result of the research, it shows that the value of the normality test with Kolmogorov-Smirnov test is 0.065 , significance value (p-value)on 0.067 is higher than 0.05 . So it can be concluded that the residual data is distributed normally.

\section{Classical Assumption Test}

1. Data Normality Test

\begin{tabular}{|c|c|c|c|}
\hline \multicolumn{4}{|c|}{ One-Sample Kolmogorov-Smirnov Test } \\
\hline & & & $\begin{array}{l}\text { Unstandardize } \\
\text { d Residual }\end{array}$ \\
\hline \multicolumn{3}{|l|}{$\mathrm{N}$} & 277 \\
\hline \multirow[t]{2}{*}{ Normal Parameters ${ }^{\mathrm{a}, \mathrm{b}}$} & & Mean & .0000000 \\
\hline & & $\begin{array}{l}\text { Std. } \\
\text { Deviatio } \\
\mathrm{n}\end{array}$ & .39015160 \\
\hline \multirow[t]{2}{*}{ Most Extreme Differences } & & Absolute & .052 \\
\hline & & $\begin{array}{l}\text { Positive } \\
\text { Negative }\end{array}$ & $\begin{array}{l}.051 \\
-.052\end{array}$ \\
\hline Test Statistic & & & .052 \\
\hline Asymp. Sig. (2-tailed) & & & $.065^{\circ}$ \\
\hline $\begin{array}{l}\text { a. } \\
\text { distribution is Normal }\end{array}$ & Test & & \\
\hline $\begin{array}{l}\text { b. } \\
\text { ulated from data }\end{array}$ & Calc & & \\
\hline $\begin{array}{l}\text { c. } \\
\text { efors Significance Correction }\end{array}$ & Lilli & & \\
\hline
\end{tabular}

From the result of the research, it shows that the value of the normality test with Kolmogorov-Smirnov test is 0.065 , significance value ( $\mathrm{p}$-value) on 0.067 is higher than 0.05 . So it can be concluded that the residual data is distributed normally.

2. Multicollinearity Test 
Table 5. Result of Multicollinearity Test

\begin{tabular}{l|l|l|l}
\hline Variable & Tolerance & VIF & Conclusion \\
\hline Internal Auditor Roles & 0.527 & 1.896 & No Multicollinearity \\
\hline Auditor Professionalism & 0.527 & 1.896 & No Multicollinearity \\
\hline
\end{tabular}

Source: SPSS 24 Data Processing Result (2020)

From the table above, it indicates that the two independent variables that are internal auditor roles and auditor professionalism have tolerance value $>0.10$ and VIF under 10. This test result indicates that variables of internal auditor roles and auditor professionalism are not correlated with each other or there is no multicollinearity on the regression model.

3. Heteroscedasticity Test

Table 6. Result of Heteroscedasticity Test

\begin{tabular}{l|l|l|l}
\hline No. & Variable & Sig. & Conclusion \\
\hline 1. & Internal Auditor Roles & 0.359 & No Heteroscedasticity \\
\hline 2. & Auditor Professionalism & 0.373 & No Heteroscedasticity \\
\hline
\end{tabular}

Source: SPSS 24 Data Processing Result (2020)

Based on Table 6 above, suggest that the two variables are free from heteroscedasticity since on the independent variables both internal auditor roles and professionalism have significance value $>0.05$.

\section{Determination Coefficient $\left(\mathbf{R}^{2}\right)$}

a. The Effect of Internal Audit Roles on Fraud Prevention

Table 7. Result of Determination Coefficient Test $\mathrm{X}_{1}-\mathrm{Y}$

\begin{tabular}{l|l|l|l|l}
\hline \multicolumn{5}{l}{ Summary Model } \\
\hline Model & $\mathrm{R}$ & $\begin{array}{l}\text { R } \\
\text { Square }\end{array}$ & $\begin{array}{l}\text { Adjusted R } \\
\text { Square }\end{array}$ & $\begin{array}{l}\text { Std. Error of the } \\
\text { Estimation }\end{array}$ \\
\hline 1 & $0.674^{\mathrm{a}}$ & 0.454 & 0.452 & 5.22496 \\
\hline a. Predictors: (Constant), Internal Audit Role
\end{tabular}

Source: SPSS 24 Data Processing Result (2020)

Based on table 7 above, the result of the determination coefficient is shown by the r-square value as 0.454 or $45.4 \%$ for the contribution of the effect of auditor professionalism on fraud prevention, while the remains as $54.6 \%$ are for the contribution of other variables outside this research.

b. The Effect of Auditor Professionalism on Fraud Prevention

Table 8. Result of Determination Coefficient Test $\mathrm{X}_{2}-\mathrm{Y}$

\begin{tabular}{l|l|l|l|l}
\hline \multicolumn{5}{l}{ Summary Model } \\
\hline Model & $\mathrm{R}$ & $\mathrm{R}$ & $\begin{array}{l}\text { Adjusted R } \\
\text { Square }\end{array}$ & $\begin{array}{l}\text { Std. Error of the } \\
\text { Estimation }\end{array}$ \\
\hline 1 & $0.585^{\mathrm{a}}$ & 0.343 & 0.340 & 5.73198 \\
\hline b. Predictors: (Constant), Auditor Professionalism
\end{tabular}

Source: SPSS 24 Data Processing Result (2020)

The result of the determination coefficient is shown by the r-square value as 0.343 or $34.3 \%$ for the contribution of the effect of auditor professionalism on fraud prevention, while the remaining as $65.7 \%$ is for the contribution of other variables outside this research.

\section{Hypothesis Test}

a. Partial Significance Test (T-Test)

$\mathrm{H}_{1}$ : Internal Audit Roles has a significant positive effect on fraud prevention 
Table 9. Result of T-Test (Hypothesis 1)

\begin{tabular}{|c|c|c|c|c|c|c|}
\hline \multicolumn{2}{|c|}{ Model } & \multicolumn{2}{|c|}{$\begin{array}{l}\text { Unstandardized } \\
\text { Coefficients }\end{array}$} & \multirow{2}{*}{$\begin{array}{l}\text { Standardized } \\
\text { Coefficients } \\
\text { Beta }\end{array}$} & \multirow[b]{2}{*}{$\mathrm{t}$} & \multirow[b]{2}{*}{ Sig. } \\
\hline & & B & Std. Error & & & \\
\hline \multirow[t]{2}{*}{1.} & (Constant) & 14.356 & 1.9340 & & 7.421 & .000 \\
\hline & $\begin{array}{l}\text { Internal Auditor } \\
\text { Roles }\end{array}$ & 0.668 & 0.044 & 0.674 & 15.119 & .000 \\
\hline
\end{tabular}

Source: SPSS 24 Data Processing Result (2020)

Based on the Table 9 above, it indicates that the result of t-test gains t-count as 15,119>t-table as 1.969 and significance (p-value) as $0.000<0.05$. Thus, Hypothesis 1 is accepted, and it can be concluded that the internal audit role has a significant positive effect on fraud prevention.

$\mathrm{H}_{2}$ : Auditor Professionalism has a significant positive effect on fraud prevention

Table 10. Result of T-Test (Hypothesis 2)

\begin{tabular}{l|l|l|l|l|l|l}
\hline \multicolumn{2}{l}{ Model } & \multicolumn{2}{l|}{$\begin{array}{l}\text { Unstandardized } \\
\text { Coefficients }\end{array}$} & $\begin{array}{l}\text { Standardized } \\
\text { Coefficients }\end{array}$ & & \\
\cline { 3 - 7 } & B & Std. Error & Beta & t & Sig. \\
\hline 1. & (Constant) & 18.414 & 2.099 & & 8.772 & .000 \\
\hline & $\begin{array}{l}\text { Auditor } \\
\text { Professionalism }\end{array}$ & 0.574 & 0.048 & 0.585 & 11.977 & .000 \\
\hline a. & Dependent Variable: Fraud Prevention & & &
\end{tabular}

Source: SPSS 24 Data Processing Result (2020)

Based on the Table 10 above, it indicates that the result of t-test gains t-count as $11.977>\mathrm{t}$-table as 1.969 and significance (p-value) as $0.000<0.05$. Thus, Hypothesis 2 is accepted, and it can be concluded that auditor professionalism has a significant positive effect on fraud prevention.

\section{Doubled Linear Regression Test}

Table 11. Result of Doubled Regression Test

Simultaneous Test on Variables $\mathrm{X}_{1}$ and $\mathrm{X}_{2}$ towards $\mathrm{Y}$

\begin{tabular}{l|l|l|l|l|l|l}
\hline \multicolumn{7}{l|}{ ANOVA $^{\text {a }}$} \\
\hline Model & & $\begin{array}{l}\text { Sum of } \\
\text { Squares }\end{array}$ & df & $\begin{array}{l}\text { Mean } \\
\text { Square }\end{array}$ & F & Sig. \\
\hline 1 & Regression & 6630.690 & 2 & 3315.345 & 127.633 & $.000^{\mathrm{b}}$ \\
\hline & Residual & 7117.304 & 274 & 25.976 & & \\
\hline & Total & 13747.994 & 276 & & & \\
\hline
\end{tabular}

a. Dependent Variable: Fraud Prevention

b. Predictors: (Constant), Auditor Professionalism, Internal Audit Roles

From the result of the test it indicates that the value of F-count as $127.633>$ F-table as 3.028, this means that internal audit role and auditor professionalism that has been simultaneously tested show that internal audit role and auditor professionalism have a significant effect on fraud prevention if tested together with the significance value lower than 0.05 $(0.005<0.05)$.

\section{Discussion}

The effects of internal audit role and auditor professionalism on fraud prevention as the moderation variable in this research were tested by partial test for the internal audit role variable towards fraud prevention and the auditor professionalism towards fraud prevention. These hypotheses have been proven by the result of the conducted research.

The indicator of professionalism in this study uses 3 indicators, namely continuous and long-term training, namely 
training carried out by all levels of auditors on a scheduled basis, whether carried out internal or external, the second indicator is the certification exam conducted by internal auditors. This test is carried out by external institutions. The third indicator is that internal auditors are members of professional organizations who regularly attend meetings of fellow members of the profession, this can be used by fellow auditors to update information regarding fraud prevention strategies, especially in the banking environment. Indicators of continuous training and auditor certification carried out by internal auditors show an index value of $64.7 \%$, while professional membership and attending internal auditor community meetings have the strongest influence, which is $65.9 \%$. This indicates that this indicator has a strong influence on capacitybuilding auditors, one of which is fraud prevention.

Meanwhile, in the dimensions of internal audit that sawyer conveyed, the 3 indicators used in this study were compliance, recommendations, and evaluation. Of these three indicators, the value has almost the same value, with a value of $65.25 \%$ for the recommendation indicator. This shows that the importance of reporting the actual condition and the importance of implementing the recommendations from the auditors as an effort to prevent fraud are the most important things. From the results of the validity test, the value ranges from 0.5 to 0.9 . This value is greater than the $\mathrm{T}$ table, namely 0.117 . This shows that all indicators of each variable, namely the role of internal audit, auditor professionalism, and fraud prevention are declared valid. Normality test shows that the data is normally distributed with a Cronchback Alpha value of more than 0.60. This shows that the variables of professionalism, internal audit, and fraud prevention are reliable.

Based on the result of linear regression, the t-count test on Internal Audit (Variable $\mathrm{X}_{1}$ ) to Fraud Prevention (Variable $\mathrm{Y}$ ), gains the $t$-count value of 15,119 . This value is higher than the $t$-table that is 1.969 meaning this indicates that the internal audit role $\left(\mathrm{X}_{1}\right)$ has a positive effect on fraud prevention, with a significance value (p-value) of 0.00 . meaning that the internal audit role has a significant positive effect on fraud prevention. The results of this study state that the role of internal audit has a significant effect on fraud prevention, this supports the theoretical basis which shows that internal audit has a major role for companies to control and evaluate company activities, especially in fraud prevention. The role of an internal audit always evaluates the effectiveness of the control system and provides internal recommendations for improvement if weaknesses are found. However, as a supervisory function, an internal audit is also needed to detect fraud that is believed to be or has occurred. Within the company, an internal audit does not have the authority to give direct orders to employees, nor is it justified to carry out operational duties in companies that are outside of inspection activities. Internal audit department management is responsible for all internal audit tasks. If all these indicators can be implemented properly, then the role of internal audit can run effectively.

The responsibility of internal auditors in minimizing fraud is strongly influenced by the support and commitment of the management in a system as stated in the institutional theory, management's commitment to be able to implement audit findings will greatly affect how much success internal audit has in its role in preventing fraud which is one of a measure of the effectiveness of internal audit, meaning that the better the management support, the better the role of internal audit in preventing fraud. The less pressure from parties who will provide legitimacy, the better the role of internal audit in fraud prevention because it is more independent, this is in line with the concept of isomorphism.

This is in line with Suginam's research (2016) which suggests that internal audit affects fraud prevention. Marsandy and Rahmaita (2018) suggest that the internal audit role has a positive and significant effect on fraud prevention.

Murniati (2009, cited in Zelmiyanti and Anita, 2015) has studied the effect of the internal auditor on fraud prevention in government and private banks in Padang City. The result of the study shows that the role of the internal auditor significantly has a positive effect on preventing fraud. In line with the previous studies, Ihsan (2008, ibid.) also proves that fraud prevention can be carried out by the role of internal auditor, wherein the study shows that internal audits significantly have a positive effect on fraud prevention. Those studies are supported by the research conducted by Robiyanto (2009) in a general bank in Jakarta, where the result shows that the roles of internal auditors in preventing and detecting fraud are much better than external auditors.

Based on the studies above, they suggest that the factor of organization cultures, internal audits, and the implementation of internal control systems significantly affect fraud prevention (Zelmiyanti and Anita, 2015). Besides, the strong organizational culture will improve the effectiveness of the implementation of the internal control system and the role of the internal auditor can affect the implementation of the internal control system in the company. The study of fraud cases in the banking industry has not been that much meanwhile the fraud issues have occurred much more in this industry.

According to social cognitive theory, good internal audit ability is obtained from the learning process, whether it is active learning directly or learning from the social environment with the encouragement of stimuli from the environment and oneself. , the auditor's ability will be better if the internal auditors do things that will increase their capabilities such as reading, conducting field orientation, reading environmental conditions, and the auditor always maintaining his professional attitude which is reflected in the independence of the auditor, the auditor's skepticism and discipline in carrying out the stages of the audit. So with the professional attitude of the internal auditors, it is expected that they can 
make a maximum contribution to preventing fraud, this supports the results of the hypothesis test that the professionalism of the auditors can affect the prevention of fraud. This supports the theoretical basis in the previous discussion which states that the professionalism of internal auditors is the key to success in running a company, internal auditors who have professionalism will carry out their duties well. Auditors who have a professional spirit always encourage themselves to realize professional work results and maintain inspection quality.Thus the earlier research conducted by Drogalas et. al., (2017) and Petrascu and Tieanu (2014) show that internal audit has a positive and significant effect in detecting fraud.

Partial Test on Variable $\mathrm{X}_{2}$ and $\mathrm{Y}$

Based on the result of the t-count test on Professionalism (Variable $\mathrm{X}_{2 \text { ) }}$ to Fraud prevention (Variable Y), it gains the $\mathrm{t}$ count value as 11.977. This value is higher than the t-table that is 1.969 meaning this indicates that auditor professionalism $\left(\mathrm{X}_{2}\right)$ has a positive effect on fraud prevention, with a significance value (p-value) of 0.00 . meaning that auditor professionalism has a significant positive effect on fraud prevention.

This result is supported by the earlier researches conducted by Andriyanti and Latrini (2019); Widaningsih and Hakim (2015); and Windasari and Juliarsa (2016) which show that auditor professionalism has a positive effect on fraud prevention.

\section{Determination Coefficient Test}

The determination coefficient test was carried on two independent variables that are internal audit role and auditor professionalism. In the determination coefficient test, the internal audit role on fraud prevention gains an r-square value of 0.454 . This indicates that the internal audit role itself affects fraud prevention as $45.4 \%$, while the remains are affected by other factors. The determination coefficient test on auditor professionalism on fraud prevention gains an $r$-square value of 0.343 . This indicates that auditor professionalism itself affects fraud prevention as $34.3 \%$ while the remains are affected by other factors.

\section{Conclusion and Suggestion}

\section{Conclusion}

Based on the results of the research, the conclusions are as follows: The roles of internal audits and auditor professionalism have a significant positive effect on fraud prevention. The roles of internal audit and auditor professionalism have a significant positive effect on fraud prevention. Since the Internal Audit Professionalism affects the Internal Audit Performance, it is necessary to include the professionalism owned by the internal audits to apply in serving or providing services in the form of any checking on the company so the internal audit performance can be improved (Ariga, 2018). The professionalism of an internal audit is necessarily needed to prevent any fraud. The higher the professionalism of an internal audit, the more guaranteed its audit quality. By having high professionalism and high organization cultures, the internal auditors are supposed to be able in detecting and especially preventing any fraud to happen in the company or organization.

\section{Suggestion}

Further researchers are expected to be able to examine more deeply which is not only limited to the variables that have been studied, but it is necessary to add or expand other variables such as the internal control system, auditor competence, and are expected to use a wider scope of research objects and should be able to use research variables other than the variables that have been examined in this research.

\section{References}

Albrecht, W. S., et al. (2011). Fraud Examination. Thomson South-Western: Cengage Learning.

Albrecht, W. S., et al. (2012). Fraud Examination, $4^{\text {th }}$ Edition. Canada South-Western: Cengage Learning.

Amrizal. (2004). Pencegahan dan Pendeteksian Kecurangan oleh Internal Auditor. Jakarta: Direktorat Investigasi BUMN dan BUMD Deputi Bidang Investigasi.

Andriyanti, D., \& Latrini, M. Y. (2019). Pengaruh Pengalaman, Independensi, dan Profesionalisme Auditor Internal dalam Mencegah Kecurangan pada Bank Perkreditan Rakyat. E-Jurnal Akuntansi, 27(1). https://doi.org/10.24843/EJA.2019.v27.i01.p18

Arens, A. A., Elder, R. J., \& Beasley, M. S. (2012). Audit dan Jasa Assurance $15^{\text {th }}$ Edition. Jakarta: Salemba Empat

Arens, A. A., Ellder R. J., \& Beasley, M. S. (2008). Auditing dan Jasa Assurance Pendekatan Terintegrasi. Jakarta: Erlangga.

Ariga, F. Z. (2018). Pengaruh Profesionalisme Audit Internal terhadap Kinerja Audit Internal dan Pencegahan Kecurangan (Fraud) pada PT. Lintas Mediatama. Jurnal Akuntansi, Audit dan Sistem Informasi Akuntansi, 2(4). 
Astuti, J. P., \& Sormin, P. (2019). Pengaruh independensi, kompetensi dan profesionalisme auditor terhadap kemampuan mendeteksi kecurangan”. JurnalAkuntansi, 13(2), Oktober 2019, 123-142. https://doi.org/10.25170/jara.v13i2

Bob, A. (2021). Tekan potensi terjadinya Fraud ini yang dilakukan BNI, 11 November 2021. retrieved from https://keuangan.kontan.co.id/news/tekan-potensi-terjadinya-fraud-oleh-karyawan-ini-yang-dilakukan-bni

Dali, N., \& Mas'ud, A. (2014). The Impact of Professionalism, Locus of Control, and Job Satisfaction on Auditors' Performance: Indonesian Evidence. International Journal of Business and Management Invention, 3(10), October, 63-73.

Drogalas, G. A., Pazarkis, M., Anagnostopoulou, E., \& Papachristou, A. (2017). The Effect of Internal Audit Effectiveness, Auditor Responsibility, and Training in Fraud Detection. Journal of Accounting and Management Information Systems, 16(4). https://doi.org/10.24818/jamis.2017.04001

Fullerton, R. R., \& Durtschi, C. (2004). The Effect of Profesional Skepticism on the Fraud Detection Skill of Internal Auditor. Retrieved on June 16, 2019.https://doi.org/10.2139/ssrn.617062

Ginanjar, Y., \& Syamsul, E. M. (2020). Peran Auditor Internal dalam Pendeteksian dan Pencegahan Fraud pada Bank Syariah di Kota Bandung. Jurnal Ilmiah Ekonomi Islam,6(3). https://doi.org/10.29040/jiei.v6i3.1392

Gusnardi, G. (2011). Pengaruh Peran Komite Audit, Pengendalian Internal, Audit Internal dan Pelaksanaan Tata Kelola Perusahaan Terhadap Pencegahan Kecurangan. EKUITAS: Jurnal Ekonomi dan Keuangan, 15(1), 130-146. https://doi.org/10.24034/j25485024.y2011.v15.i1.2283

Hery. (2010). Potret Profesi Audit Internal. Bandung:Alfabeta.

Institute of Internal Auditors (IIA). (2005). International standards for the professional practice of internal auditing. Retrieved from http://www.theiia.org/?doc id=499

Kumaat, V. G. (2011). Internal Audit. Jakarta: Penerbit Erlangga

Listriyantie, Y. (2016). Pengaruh Kompetensi dan Profesionalisme Auditor Kepabeanan dan Cukai terhadap Kualitas Audit dan Dampaknya terhadap Kecurangan Pelaporan Keuangan Importir dan Eksportir. Retrieved from https://repository.mercubuana.ac.id/39008/

Maliawan, B. I. D., et. al. (2017). Pengaruh Audit Internal terhadap Pencegahan Kecurangan (Fraud) (Studi Empiris pada Bank Mandiri Kantor Cabang Area Denpasar). Jurnal Akuntansi, 8(2).

Marsandy, E. D., \& Rahmaita, R. (2018). Pengaruh Peran Audit Internal terhadapPencegahan Fraud (Studi Kasus pada PT Semen Padang). Jurnal Ekonomi dan Bisnis Dharma Andalas, 20(2).

Munteanu, C., Coebanu, C., Stoian, C. I., \& Tugulea, O. (2010). An Analysis of Customer Satisfaction in a Higher Education Context. International Journal of Public Sector Management, 23(2), 124-140. https://doi.org/10.1108/09513551011022483

Murniati. (2009). Pengaruh Pelaksanaan Pengandalian Internal dan Peran Audit Internal Terhadap Pencegahan Kecurangan di Lembaga Perbankan Kota Padang. Padang: Paper FE UNP.

Neli, I. (2009). Pengaruh Peran Auditor Internal Terhadap Efektivitas Penerapan Struktur Pengendalian Internal (Studi Pada BUMN Kota Padang). Padang: Paper FE UNP

Nurhayanto. (2013). Sistem Kendali Kecurangan (Fraud) Perbankan. Jakarta: Tinta

Otoritas Jasa Keuangan. (2019). Peraturan Otoritas Jasa Keuangan Nomor 13/POJK.03/2019 Tentang Pelaporan Bank Perkreditan Rakyat dan Bank Pembiayaan Rakyat Syariah melalui Sistem Pelaporan Otoritas Jasa Keuangan. Retrieved Juni 9, 2020. from ojk.go.id.

Petrascu, D., \& Tieanu, A. (2014). The Role of Internal Audit in Fraud Prevention and Detection. Procedia Economics and Finance, Vol. 16 No. 6, 489-497. https://doi.org/10.1016/S2212-5671(14)00829-6

Ramadhaniyati, Y., \& Hayati, N. (2014). Pengaruh Profesionalisme, Motivasi, Integritas, dan Independensi Satuan Pengawasan Internal Dalam Mencegah Kecurangan (Fraud), 2(2), 101-114.

Rangga, A. M. (2015). Analisis Pengaruh Lingkungan Kerja, Budaya Organisasi dan Motivasi Kerja Terhadap Kepuasan Kerja Pegawai Badan Kesehatan Olah Raga Masyarakat dan Pelatihan Kesehatan Provinsi Sumatera Barat (BKOM \& PELKES). eSkripsi Universitas Andalas. Padang: University of Andalas

Riba'ati, M. (2003). Faktor-Faktor yang Mempengaruhi Mahasiswa dalam Akuntansi Keuangan di Perguruan Tinggi Swasta. Jurnal, 3(1), June 2003, 321-342.

Robbins, P. S. (2002). Prinsip-Prinsip Perilaku Organisasi, edisi 5. Jakarta: Erlangga 
Robiyanto, F. (2009). Persepsi Auditor Mengenai Metode Pendeteksi dan Pencegah Tindakan Kecurangan Pada Industri Perbankan. Paper: Program Pascasarjana Universitas Diponegoro.

Sawyer, L. B., Dittenhofer, M. A., \& Scheiner, J. H. (2006). Sawyer's Internal Auditing (3 ${ }^{\text {rd }}$ edition). Jakarta: Salemba Empat

Schein, E. H. (2004). Organizational Culture and Leadership 3rd edition. San Fransisco: John Wiley \& Sons, Inc.

Sekaran, U. (2014). Metodologi Penelitian Untuk Bisnis (Research Methods for Business) Buku 1 Edisi 4. Jakarta: Salemba Empat.

Soepardi, E. A., Iskandar, N., Bashiruddin, J., \& Restuti, R. D. (ed). (2012). Buku Ajar Ilmu Kesehatan Telinga, Hidung, Tenggorokan, Kepala dan Leher, $7^{\text {th }}$ edition. Jakarta: Balai Penerbit FKUI 2007

Suastawan, M. I. D. P., Sujana, E., \& Sulindawati, N. L. G. E. (2017). Pengaruh Budaya Organisasi, Proactive Fraud Audit, dan Whistleblowing terhadap Pencegahan Kecurangan dalam Pengelolaan Dana Bos. E-Journal Undiksha, Jurnal Ilmiah Mahasiswa, 7(1).

Suginam. (2016). Faktor-Faktor yang Mempengaruhi Audit Report Lag pada Perusahaan Sektor Perdagangan Jasa dan Investasi yang Terdaftar di Bursa Efek Indonesia. ISSN. Vol XI, No. 1

Sugiyono. (2010). Metode Penelitian Pendidikan Pendekatan Kuantitatif, kualitatif, dan R\&D. Bandung: Alfabeta.

Surjandari, D. A., \&Martaningtyas, I. (2019). An Empirical Study: The Effect of Performance Incentives, Internal Control System, Organizational Culture on Fraud of Indonesia Government Officer. Mediterranean Journal of Social Sciences MCSER Publishing, Rome-Italy, 6(555), Oktober 2015 ISSN 2039-2117 (online) ISSN 2039-9340 (Print). https://doi.org/10.5901/mjss.2015.v6n5s5p71

Tampubolon, N. (2016). OJK: Kunci Pencegahan Fraud di Internal Bank. Diakses pada 2 Juni 2019 dari World Wide Web: http://infobanknews.com/ojk-kunci-pencegahan-fraud-di-internal-bank/

Tunggal, A. M. (2012). Audit Kecurangan dan Akuntansi Forensik. Jakarta: Harvarindo.

Tunggal, A. W. (2010). Dasar-dasar Audit Internal Pedoman untuk Auditor Baru. Jakarta: Harvarindo.

Tunggal, A. W. (2011). Teori dan Kasus Kecurangan Akuntansi dan Keuangan. Jakarta: Harvarindo.

Wati, D. I. P. (2019). Pengaruh Budaya Organisasi, Peran Audit Internal, Pengendalian Internal, Dan Whistleblowing Terhadap Pencegahan Fraud. Paper: Muhammadiyah University

Widaningsih, M., \& Hakim, D. N. (2015). Pengaruh Profesionalisme Auditor Internal Terhadap Pencegahan dan Pendeteksian Kecurangan (Fraud). Jurnal Riset Akuntansi dan Keuangan, 3(1), 586-602. https://doi.org/10.17509/jrak.v3i1.6606

Wijaya, C. (2010). Pengaruh Audit Internal terhadap Perwujudan A Good Corporate Governance pada PT. KAI (Persero) Bandung. Undergraduate thesis, Maranatha Christian University

Wijaya, C. L., \& Pesudo, D. A. A. (2020). Pengaruh Profesionalisme dan Independensi terhadap Pencegahan Kecurangan dengan Iklim Etika-Egoisme sebagai Variabel Moderasi. Jurnal Ilmu Sosial dan Humaniora, 9(1). p-ISSN: 23032898 e-ISSN: 2549-6662. https://doi.org/10.23887/jish-undiksha.v9i1.24230

Windasari, M. Y., \& Juliarsa, G. (2016). Pengaruh Kompetensi, Independensi, dan Profesionalisme Auditor Internal dalam Mencegah Kecurangan pada BPR di Kabupaten Badung. E-Jurnal Akuntansi, 17(3). https://doi.org/10.24964/ja.v3i1.1

Wulandari, D. N., \& Nuryanto, M. (2018). Pengaruh Pengendalian Internal, Kesadaran Anti-Fraud, Integritas, Independensi, dan Profesionalisme terhadap Pencegahan Kecurangan. Jurnal Rise Akuntansi MercuBuana, 4(2). https://doi.org/10.26486/jramb.v4i2.557

Wulandari, S. (2014). Analisis Faktor-Faktor yang Mempengaruhi Auditor dalam Memberikan Opini Audit Going Concern. E-Jurnal Akuntansi, 6(3).

Zelmiyanti, R. \& Anita, L. (2015). Pengaruh Budaya Organisasi Dan Peran Auditor Internal Terhadap Pencegahan Kecurangan Dengan Pelaksanaan Sistem Pengendalian Internal Sebagai Variabel Intervening. Jurnal Akuntansi Keuangan dan Bisnis, 8, November 2015, 67-76.

\section{Copyrights}

Copyright for this article is retained by the author(s), with first publication rights granted to the journal.

This is an open-access article distributed under the terms and conditions of the Creative Commons Attribution license which permits unrestricted use, distribution, and reproduction in any medium, provided the original work is properly cited. 